\title{
IMPACT OF INTEGRATED NUTRIENT MANAGEMENT ON GINGER PRODUCTION
}

\author{
AK SINGH ${ }^{*}$, US GAUTAM ${ }^{1}$ AND JAI SINGH ${ }^{1}$ \\ Jawaharlal Nehru Krishi Vishwa Vidyalaya, Krishi Vigyan Kendra, Katni-483 442 (MP), India
}

Key words: Impact, Integrated nutrient, Ginger production, Management

\begin{abstract}
An experiment was evaluated in an integrated approach of nutrient management on two ginger cultivars under irrigation domains in Kymore Plateau and Satpura Hills zone of central India for three consecutive years during the kharif season. The results revealed that the weight of rhizomes per plant and fresh rhizome yield together with VC ratio were noted to be significantly higher (229.9 g and $22754 \mathrm{~kg} / \mathrm{ha}$ ) in improved cultivar Suprabha with integrated nutrient management (INM) in partial shade than the same genotype with INM without shade (216.4 g and $21692 \mathrm{~kg} / \mathrm{ha})$. The lowest rhizome per plant and fresh rhizome yield was recorded in farmers' practice (without shade) with Local cultivar (154.7 g and $16698 \mathrm{~kg} / \mathrm{ha}$ ). The technology gap and technology index were minimum in improved cultivar Suprabha with INM due to partial shade resulting an additional 5 employment.
\end{abstract}

Ginger (Zingiber officinale Rosc.), is the most popular 'hot spice' in the world. Ginger rhizomes and their products are consumed as a special vegetable in daily diets together with culinary and medicinal use. It is cultivated in India, China, Japan, Indonesia, Australia, Nigeria and the West Indies. India is the largest producer and consumer of ginger in the world. Kerala is the largest ginger producing state, accounting for about 33 per cent of the total production in India. Out of the total production of ginger in India, about 30 per cent is converted into dry ginger, 50 per cent consumed as green ginger as a vegetable and the rest is used for propagation. India contributes about 36 per cent of the world's total ginger production; however, its share in the ginger trade is only 6 per cent as against China's 57 per cent. The dried ginger (called saunth) or ginger powder is generally used in manufacturing of ginger brandy, wine and beer in many western countries. Ginger oil is primarily used as a flavoring agent in confectionary and for soft drinks (Yadav et al. 2004).

In Madhya Pradesh, Tikamgarh and Chhindwara are important ginger growing districts; however, in the other districts such as Katni, it is also grown in substantial areas either as a sole or as an intercrop. The productivity in this area is reasonably low which is perhaps due to use of local varieties susceptible to several serious diseases such as rhizome rot and to inadequate and imbalanced use of fertilizers. Demand for this spice crop is increasing progressively as fresh ginger or in processing and export industries. The present study was therefore carried out in Katni district falls within the Kymore Plateau and Satpura Hills zone of central India during 2007-2008 to 2009-2010 to assess the impact of integrated nutrient management, on growth and yield of local and improved variety of ginger (suprabha).

The study was conducted at selected farmers' fields of Katni district (Madhya Pradesh) in kharif season during 2007-2008 to 2009-2010. The crop was sown in the second half of May during 2007 to 2009.

*Author for corresponding: <singhak123@rediffmail>. ${ }^{1}$ Jawaharlal Nehru Krishi Vishwa Vidyalaya, Krishi Vigyan Kendra, Katni-483 442 (MP), India. 
Seeds of Suprabha variety and Local variety were used at the rate of 1 and $1.5 \mathrm{t} / \mathrm{ha}$, respectively. NPK were applied @ $75: 50: 50 \mathrm{~kg} / \mathrm{ha}$ in the form of urea, DAP and MOP, respectively. Whole $\mathrm{P}, \mathrm{K}$ and half of the $\mathrm{N}$ were side dressed at the sowing time, while the remaining $\mathrm{N}$ was top dressed in two splits at 70 and 120 days after sowing, respectively. Mulching with tree dry leaves was done at sowing and 80 days after sowing. Frequent irrigations were applied as per requirement. One earthing at 70 days after sowing together with all other agronomic practices were done uniformly in all treatments except farmers' practice. The crop was harvested manually in the second fortnight of December, 2008, 2009 and 2010, respectively. The trial was laid out at farmers' fields ( 0.2 ha each) at five locations. The experiment comprised of five treatments viz., $T_{1}$ (Farmers' practice- Local cultivar, NPK @ $22: 57: 0 \mathrm{~kg} / \mathrm{ha}$ without shade), $\mathrm{T}_{2}$ (Local cultivar, NPK @ $75: 50: 50$ kg/ha and FYM @ 20 t/ha without shade), $T_{3}$ (Local cultivar, NPK@ $75: 50: 50 \mathrm{~kg} / \mathrm{ha}$ and FYM @ $20 \mathrm{t} / \mathrm{ha}$ in partial shade), $\mathrm{T}_{4}$ (Improved cultivar Suprabha, NPK@75:50:50 kg/ha and FYM @ 20 t/ha without shade) and $T_{5}$ (Improved cultivar Suprabha, NPK@ 75 : 50:50 kg/ha and FYM@ 20 t/ha in partial shade).To maintain the partial shade (approx. 50 per cent), fields with surrounding trees on the bunds and plantation inside were selected. Data on growth and yield were recorded at maturity and analyzed statistically (Steel et al. 1997). The feasibility of technology in the trial was workout through technology gap and index (Kadian et al. (1997).

Technology gap $=($ Potential Yield - Trial Yield $)$

Technology index $=(\mathrm{P}-\mathrm{T} / \mathrm{P}) \times 100$,

where, $\mathrm{P}=$ Potential yield, $\mathrm{T}=$ Trial yield.

The results presented in Table 1 reveal that weight of rhizomes per plant and yield per ha varied significantly between the genotypes with INM. The weight of rhizomes per plant was highest in Suprabha with INM in partial shade (229.9 g) followed by the same genotype with INM without shade (216.4 g). Similar findings were reported by Kumar et al. (2006) in their experiment conducted at Dhaulakuan (Himanchal Pradesh). The least rhizome weight per plant was recorded

Table 1. Effect of integrated nutrient management on growth, yield, technology gap and index of local and improved cultivar (Suprabha) of ginger (Av. of 3 years).

\begin{tabular}{ccccccc}
\hline Treatments & $\begin{array}{c}\text { Weight of } \\
\text { rhizomes/plant (g) }\end{array}$ & $\begin{array}{c}\text { Yield } \\
(\mathrm{kg} / \mathrm{ha})\end{array}$ & $\begin{array}{c}\mathrm{V}: \mathrm{C} \\
\text { ratio }^{\#}\end{array}$ & $\begin{array}{c}\text { Variety potential Technology gap } \\
\text { yield }(\mathrm{kg} / \mathrm{ha})\end{array}$ & $\begin{array}{c}\text { Technology index } \\
(\mathrm{kg} / \mathrm{ha})\end{array}$ & $\begin{array}{c}\text { To) } \\
(\mathrm{T})\end{array}$ \\
$\mathrm{T}_{1}$ & 154.7 & 16698 & 3.42 & - & - & - \\
$\mathrm{T}_{2}$ & 163.4 & 18023 & 3.59 & - & - & - \\
$\mathrm{T}_{3}$ & 169.5 & 18770 & 3.74 & - & - & - \\
$\mathrm{T}_{4}$ & 216.4 & 21692 & 3.93 & 22800 & 1108 & 4.86 \\
$\mathrm{~T}_{5}$ & 229.9 & 22754 & 4.12 & 22800 & 46 & 0.20 \\
\hline$(\mathrm{p}<0.05)$ & 6.28 & 0.54 & - & - & - & - \\
\hline
\end{tabular}

"Value: Cost ratio (Gross return/Gross cost).

in farmers' practice with Local cultivar (154.7 g). Local cultivar with INM without shade and in partial shade produced 163.4 and $169.5 \mathrm{~g}$ rhizome yield/plant, respectively which was significantly higher than farmers' practice. Significant difference was also observed between Local and improved cultivar (Suprabha) with reference to rhizome yield/plant under both conditions. The Suprabha variety produced significantly higher rhizome yield per hectare (22754 $\mathrm{kg}$ ) with INM in partial shade followed by the same cultivar with INM without shade (21692 kg). These findings are in agreement with those of Lujiu Li et al. (2010) who also reported similar 
results. The local cultivar produced significantly lower rhizome yield per hectare over farmers' practice $(16698 \mathrm{~kg})$. Local variety with INM without shade and in partial shade produced 18023 and $18770 \mathrm{~kg} / \mathrm{ha}$ rhizome yield, respectively which was also significantly higher to that of farmers' practice. The value : cost ratio analyzed for the study treatment suggests that it increased by 0.17 to 0.32 units in $T_{2}$ and $T_{3}$ treatments over farmers' practice, however, in Suprabha with INM without shade and in partial shade, the $\mathrm{V}$ : C ratio was much higher ( 0.51 and 0.80 units, respectively) than for farmers' practice. The increase in average yield in Suprabha with INM without shade and in partial shade condition was 29.9 and 36.3 per cent respectively over farmers' practice. The technology gaps in the above combinations were found as 1108 and $46 \mathrm{~kg} / \mathrm{ha}$, respectively over farmers' practice. These findings signify that these technological combinations are suitable for the area especially in Suprabha with INM under partial shade condition the yield of which was very close to that of the cultivar potential. The technology index of the above was much less $(0.20 \%)$ than that of Suprabha with INM without shade (4.86\%). The above findings also suggest that balanced application of nutrients through organic and inorganic sources together with improved cultivar raises the rhizome yield especially in partial shade conditions and viable in minimizing the technology gap.

The data presented in Table 2 dealing with economic and socio-economic impacts of the improved cultivar reflect that an additional yield of 4994 and $6056 \mathrm{~kg} / \mathrm{ha}$ was recorded in $\mathrm{T}_{4}$ (Suprabha with INM without shade) and in $\mathrm{T}_{5}$ (Suprabha with INM in partial shade) treatments, respectively over $\mathrm{T}_{1}$ (farmers' practice). The gap in rhizome yield between improved cultivars' (Suprabha) potential and farmers' practice was observed $6102 \mathrm{~kg} / \mathrm{ha}$. An additional net return of Rs 87132 and 108372 per ha obtained in $\mathrm{T}_{4}$ and $\mathrm{T}_{5}$ treatments, respectively in comparison to that of $\mathrm{T}_{1}$ (farmers' practice). The socio-economic impact of the study was observed in terms of additional employment generation which indicated that 21 and 26 additional man-day/ha were engaged for harvesting of ginger rhizomes in $T_{4}$ and $T_{5}$ treatments, respectively in comparison to that of $\mathrm{T}_{1}$ (farmers' practice).

Table 2. Change in yield and net return of local and improved cultivar (Suprabha) of ginger with integrated nutrient management.

\begin{tabular}{lccc}
\hline \multicolumn{1}{c}{ Comparison } & $\begin{array}{c}\text { Additional yield } \\
\text { (kg/ha) }\end{array}$ & $\begin{array}{c}\text { Additional net return } \\
\text { (Rs./ha) }\end{array}$ & $\begin{array}{c}\text { Additional employment } \\
\text { generation (man days/ha) }\end{array}$ \\
\hline $\begin{array}{l}\text { Farmers vs Improved cv. with } \\
\text { INM without shade }\end{array}$ & $4994^{*}$ & 87132 & 21 \\
$\begin{array}{l}\text { Farmers vs Improved cv. with } \\
\text { INM in partial shade }\end{array}$ & $6056^{* *}$ & 108372 & \\
Farmers vs Variety potential & $6102^{@}$ & 109292 & - \\
\hline
\end{tabular}

*Yield difference between $\mathrm{T}_{4}$ and $\mathrm{T}_{1} \cdot{ }^{* *}$ Yield difference between $\mathrm{T}_{5}$ and $\mathrm{T}_{1}$; ${ }^{@}$ Difference between Suprabha yield potential and farmers practice yield.

On the basis of above findings it may be concluded that yield enhancement was more pronounced in improved cultivar Suprabha with INM especially in partial shade suggests that the improved cultivar 'Suprabha' performs very well in partial shade. The above combination also reduced the technology gap and index which shows its viability in the study area. The study also reflected its socio-economic impact in terms of additional employment generation. 


\section{References}

Kadian KS, Sharma R and Sharma AK 1997. Evaluation of frontline demonstration trials on oilseeds in Kangra Vally of Himachal Pradesh. Ann. Agri. Res. 18: 40-43.

Kumar P, Basandrai AK and Thakur HL 2006. Effect of different shading crops on growth, yield and economics of ginger (Zingiber officinale Rose.). Himachal J. Agri. Res. 32 (2): 33-35.

Lujiu Li, Fang Chen, Dianli Yao, Jiajia Wang, Nan Ding, and Xiyu Liu 2010. Balanced fertilization for ginger production - Why potassium is important. Better Crops 94 (1): 25-27.

Steel RGD, Torrie JH, Dickey D 1997. Principles and Procedures of Statistics: A Biometrical Approach. (3rd Ed. McGraw Hill Book Co. Inc. New York), pp. 172-77.

Yadav RK, Yadav DS, Rai N, Sanwal SK and Sarma P 2004. Commercial prospects of ginger cultivation in north-eastern region. ENVIS Bulletin: Himalayan Ecology. 12(2): 1-5.

(Manuscript received on 3 March, 2015; revised on 15 April, 2015) 